 \\ Scientific Communication
}

\section{Effect of chewing of Erythroxylum coca Lamarck (Coca) on cholesterol and serum triglyceride levels} in high andean people

\author{
Efecto de la masticación de Erythroxylum coca Lamarck (Coca) sobre los niveles de colesterol y \\ triglicérido sérico en personas altoandinas
}

\author{
Ñaccha-Urbano Jesús Javier* ${ }^{*}$
}

\begin{tabular}{l}
\hline Data of the Article \\
\hline National University of San Cristóbal de Huamanga \\
(UNSCH). \\
Biological Sciences Faculty. \\
Independence Portal N ${ }^{\circ} 57$. \\
Huamanga, Ayacucho. \\
Peru. \\
*Contact address: \\
National University of San Cristóbal de Huamanga \\
(UNSCH). \\
Biological Sciences Faculty. \\
Independence Portal N ${ }^{\circ} 57$. \\
Huamanga, Ayacucho. \\
Peru.Tel: +51 (066)31-3433 \\
Jesús Javier Naccha-Urbano \\
E-mail address : jesus.naccha@ unsch.edu.pe
\end{tabular}

\section{Palabras clave:}

\section{Coca,}

colesterol,

triglicéridos,

actividad enzimática,

masticadores,

alto andinos.

\section{J. Selva Andina Res. Soc.} 2021; 12(1):64-76. ID of article: 147/JSARS/2020

\section{Record from the article}

Received September 2020 Returned November 2020

Accepted November 2020

Available online, February 2021

\section{Edited by:}

Selva Andina

Research Society

\section{Journal of the Selva Andina Research Society ${ }^{\circledR}$. Bolivia. Todos los derechos reservados.}

La investigación tuvo como objetivo, determinar el efecto de la masticación de Erythroxylum coca Lamarck (Coca) sobre los niveles de colesterol y triglicéridos séricos en personas altoandinas, la población fue de 100 personas altoandinas, 50 mujeres y 50 varones como masticadores, conformando grupos control con personas no masticadoras. Previa entrevista y los exámenes de laboratorio se obtuvieron los siguientes resultados, para el grupo control: los niveles de colesterol (201.75 mg\% varones y $193.50 \mathrm{mg} \%$ mujeres) y niveles de triglicéridos (174 mg\% varones y $134 \mathrm{mg} \%$ mujeres). En comparación con el grupo de problema o masticadores: cuyos niveles de colesterol (155 mg \% varones y $150 \mathrm{mg} \%$ mujeres) y niveles de triglicéridos (84 mg \% varones y 55 mg \% mujeres) siendo estadísticamente significativos con la prueba de ANVA y el coeficiente de correlación simple es positiva y directa. Por lo que se concluye: que las personas que realizan la masticación de hojas de coca no son obesas. Además, el extracto de hojas de coca no facilita la digestión de alimentos grasos como el colesterol y triglicéridos al inhibir la actividad enzimática.

\section{Abstract}

The objective of the research was to determine the effect of chewing Erythroxylum coca. Lamarck (Coca) on serum cholesterol and triglyceride levels in high Andean people, the population was 100 high Andean people, 50 women and 50 men as chewers, forming control groups with non-chewers. After an interview and laboratory tests, the following results were obtained for the control group: cholesterol levels $(201.75 \mathrm{mg} \%$ men and 193.50 mg \% women) and triglyceride levels (174 mg \% men and $134 \mathrm{mg} \%$ women). Compared with the problem group or chewers: whose cholesterol levels $(155 \mathrm{mg} \%$ men and $150 \mathrm{mg} \%$ women) and triglyceride levels (84 $\mathrm{mg} \%$ men and $55 \mathrm{mg} \%$ women) being statistically significant with the ANVA test, and the simple correlation coefficient is positive and direct. Therefore, it is concluded: that people who chew coca leaves are not obese. In addition, the extract of coca leaves does not facilitate the digestion of fatty foods such as cholesterol and triglycerides by inhibiting the enzymatic activity.

Keywords:

Coca,

cholesterol,

cholesterol,
triglycerides,

enzyme activity,

chewers,

high andean. 


\section{Introduction}

Scientifically called "coca", Erythroxylum coca Lamarck, is a plant resource widely used by the inhabitants of the South American Andes. It is grown in warm areas of the Amazon rainforest for traditional chewing purposes, as well as other legal and non-legal purposes.

According to the Andean worldview, the use of coca leaves (CL), is a way of evaluating their use throughout the historical process, as a cultural element of our Andean society, thus, the ancestral, millenary use by pre-Columbian cultures, respecting the different economic, social and cultural activities. This worldview remains latent and, strengthens as society progresses, being susceptible to incorporating new elements to preserve its validity ${ }^{1}$.

The name derives from the Aymara term "Kkoka" which means divine plant, in Quechua "mama coca" mother coca. The dried leaves of this plant have been found in tombs dating back to the $4^{\text {th }}$ century BC. During the Inca times, this plant was considered divine, reserved essentially for religious activities, only used by the Inca royalty. When the Spanish conquered the Inca empire, the natives were forced to work in agricultural lands, gold and silver mines, and to give them resistance, reduce hunger, thirst, they were continuously supplying CL, in proportion to the severity of the work. required. During the time of Spanish domination, the chewing habit of CL spread in the South American Andes, from Colombia, Ecuador, Peru, Bolivia, northern Chile, and Argentina, losing its religious magic character, eventually replacing salt, because it was used as payment to the workers of the gold and silver mines $\stackrel{2}{ }$.

65
In 1858 Niemann and Walter in Germany isolated cocaine, the active alkaloid of coca, at first it was applied in human medicine for its anesthetic properties, later as a detoxifier. The consumption of this alkaloid was quickly introduced into European and American high society. Despite Mortimer's work, where he marked the difference between coca and cocaine, they contrasted with Freud's conclusions, who classified coca as a stimulant, not a narcotic, but ended up being classified as a drug for pharmacological companies ${ }^{3}$.

The production of the coca leaf has been and perhaps will continue to be a problem on the national agenda for a long time, since for many the coca leaf will continue to be that important element of traditional culture and the economic livelihood of poor families in the Andes Peruvians ${ }^{4}$.

In this regard, there are research works carried out by Chaud et $\mathrm{al}^{5}$. that determined total and fractionated proteins in indigenous people who chewed coca. Ungaro ${ }^{\underline{6}}$ investigates oral pathology in coca leaf chewers ${ }^{6}$. Caravedo-Carranza \& AlmeidaVargas $^{\underline{Z}}$ suppose that the green leaf of coca mostly constitutes alkaloids and the rest are minerals and water. Cabieses ${ }^{\underline{8}}$ published his research on the ethnology, physiology, and pharmacology of coca and cocaine. Ochoa et al. ${ }^{9}$ carried out the investigation of total proteins in coca leaf chewers. CorderoVilca $^{2}$ makes the nutritional evaluation of the protein of coca leaves ${ }^{1}$. Obregón-Lujerio ${ }^{\underline{10}}$ carried out the transformation of coca leaves into bread for human consumption and its socio-economic and environmental impact.

Zavaleta-Martínez ${ }^{11}$ makes a publication with the title "Fallacies about the coca leaf, its chemical 
components, medicine and addiction" where they propose the legalization of the use of coca, and some naturopathic organizations disseminate the document entitled "Anatomy of the coca leaf Erytroxylum coca "in which they expose the medicinal properties and therapeutic value of the coca leaf, in which nutritional and medicinal therapeutic properties are attributed to the coca leaf, aspects about the chemistry, and assumptions about the pharmacokinetics of cocaine, and its role in addiction. This document presents the position of the Center for Information and Education for the Prevention of Drug Abuse (CEDRO), in relation to these alleged medicinal properties of the coca leaf and its derivatives, chemistry, and human addiction. This CEDRO article does not agree with the publication of the aforementioned authors on the medicine and therapeutic properties of the coca leaf. From this perspective, taking into account that this plant serves as the basis for the processing of toxic substances that cause addiction and that generate social problems such as drug addiction and violence. In the research background, it is also necessary to touch on the other part of the research that has to do with the Andean worldview, for this reason, we made an outline of topics related to this topic which we will cite below, to better contextualize our Re$\operatorname{search}^{11}$.

Currently, the importance of Bolivians and Peru is to investigate and discover new nutritional and healing properties of CL. The curative potential comes from the fourteen alkaloids that make it up, one of them is cocaine, which, naturally, only has beneficial effects on the body, due to the minute amounts $(0.8 \%)$ in which the natural coca leaf occurs raw ${ }^{12}$. The reason for our research within the high Andean population was to find out if they use processed or junk foods based on fats or lipids, despite the propaganda by the media they influence the children of peasants, farmers, and small ranchers. Many are leaving their habits of feeding on products of the land: vegetable grains, tubers, legumes, vegetables, trout meat, guinea pig, and alpaca. Compared with the city population, who eat fried chicken on the grill, grills of beef and sheep, pork rinds, and the aforementioned foods, called junk or processed foods ${ }^{12}$. However, within the high Andean people there is a sector of extreme poverty: the chewers of coca leaves, only use coca leaves as a means to avoid hunger. They even migrate to the cities with this custom, in various tasks, whose earnings are used to educate their children.

Cholesterol, a lipid with very little soluble in water, whose concentration in the plasma of healthy individuals is 150 to $200 \mathrm{mg} / 100 \mathrm{~mL}^{\frac{13}{3}}$. The very high solubility of cholesterol in the blood is due to the presence of plasma lipoproteins (mainly LDL and VLDL) that have the ability to fix and therefore solubilize large amounts of cholesterol ${ }^{13}$.

Triacylglycerides come from three main sources: diet, de novo biosynthesis, especially in the liver, and existing stores in adipocytes. The main problem that animals must face in the digestion, absorption, and transport of lipids from food is the insolubility of these substances in aqueous media. However, because adipocytes lack glycerol kinase, glycerol-3phosphate to re-synthesize triacylglycerides must come from glycolysis. Glycerol is returned from adipocytes to the liver to re-synthesize glucose through gluconeogenesis ${ }^{14}$.

It is also noteworthy the observation that obesity is increasing in developing countries or "emerging economies", a higher prevalence than malnutrition and thus becoming, according to the approach, the 
main nutritional disease in those places. These characteristics apply very closely to Latin America, where poverty effectively coincides with increasing rates of malnutrition in the Andes and obesity on the coast, where the presence of the obese poor is dominant. Obesity determines a poor state of health that reduces physical activity, decreases productivity and work performance, conditioning a low level of income $\underline{15}$.

Finally, the objective was to determine the effect of chewing Erythroxylum coca Lamarck (Coca) on cholesterol and serum triglyceride levels in high Andean people.

\section{Materials and methods}

The research was carried out from April to October in the laboratory of the Ayacucho Support Hospital, belonging to the Ministry of Health, department of Ayacucho located at 2761 meters above sea level, between the geographical coordinates $13{ }^{\circ} 09^{\prime} 26^{\prime \prime}$ south latitude and $74^{\circ} 13^{\prime} 22$ West longitude, with an average temperature of $17.7^{\circ} \mathrm{C}$ and the life zone: subtropical lower montane spiny steppe (ee-MBS) ${ }^{15}$. The experimental unit (UE) was made up of peasant people from high Andean areas, from a population of 100 people, 50 men (average age 50 years) and 50 women (age 45 years), they were selected at random and according to the criteria of inclusion: only coca leaf chewers and adults, forming two groups: one control and the other problem.

Regarding the results of the control group: cholesterol levels (201.75 mg\% men and $193.50 \mathrm{mg} \%$ women) and triglyceride levels (174 $\mathrm{mg} \%$ men and $134 \mathrm{mg} \%$ women) being statistically significant with the ANOVA test compared to the problem or case group, whose cholesterol levels $(155 \mathrm{mg} \%$ men and $150 \mathrm{mg} \%$ women) and triglyceride levels (84 $\mathrm{mg} \%$ men and $55 \mathrm{mg} \%$ women) statistically significant. The inclusion criterion was that they are coca leaf chewers, and informed consent was also obtained.

For the clinical diagnosis to obtain biological data it was compiled in a data collection sheet. The collection of blood samples was performed on an empty stomach twice, the venous blood was placed in vacutainer tubes, from the median basilic and cephalic vein of the forearm, by direct puncture with disposable needles No. $21 \mathrm{G}$ in the previously disinfected area, they were placed in coolers to the $\mathrm{Hu}$ man Biology laboratory at the National University of San Cristóbal de Huamanga (UNSCH), where the blood sample was centrifuged at $3000 \mathrm{rpm}$ for $5 \mathrm{~min}$ until obtaining the required serum and performing the laboratory tests.

The modified Lieberman-Burchard method for the determination of serum cholesterol, cholesterol is determined by the action of the enzymes cholesterol ester hydrolase and cholesterol oxidase. The first liberates cholesterol from cholesterol esters, and the second oxidizes free cholesterol, producing hydrogen peroxide, which in the presence of the enzyme peroxidase reacts with the chromogenic system, giving rise to a colored compound that absorbs at $505 \mathrm{~nm}^{\underline{16}}$.

Triglycerides are hydrolyzed by a specific lipase releasing fatty acids and glycerol. Glycerol is phosphorylated by the glycerol-kinase enzyme and subsequently, glycerol-1-phosphate is oxidized to dihydroxyacetone phosphate by the glycerol-phosphate oxidase enzyme, generating hydrogen peroxide. 
Subsequently, in a Trinder-type reaction, hydrogen peroxide reacts with 4-Aminoantipyrine and 3,5Dichloro-2-Hydroxy-benzenesulfonic acid to produce by means of the peroxidase enzyme a colored compound in an amount proportional to the concentration of triglycerides present in the sample, the absorbance is measured at $520 \mathrm{~nm}$. According to the following reactions ${ }^{17}$.

To collect and order the results of the biochemical analysis such as age, weight, and height, the statistical program SPSS version 21 and Microsoft Office Excel Windows were used. To test whether the categorical variables are related or not, the analysis of variance test is used.

\section{Results}

Table 1 General data of the variables age, weight, and height of people who chew coca leaves and non-chewers of both sexes

\begin{tabular}{ccccc}
\hline \multirow{2}{*}{ Variables } & \multicolumn{3}{c}{ People } \\
\cline { 2 - 5 } & \multicolumn{2}{c}{ No Chewers } & \multicolumn{2}{c}{ Chewers } \\
\hline & Men & Women & Men & Women \\
Age (years) & 45 & 40 & 50 & 45 \\
Weigth (kg) & 80 & 65 & 70 & 60 \\
Size (m) & 1.68 & 1.55 & 1.61 & 1.50 \\
\hline
\end{tabular}

Table 2 Serum cholesterol and triglyceride averages $(\mathrm{mg} \%)$ in coca leaf chewers and non-chewers

\begin{tabular}{ccccc}
\hline \multirow{2}{*}{ Tests Serums } & \multicolumn{3}{c}{ People s } \\
\cline { 2 - 5 } & \multicolumn{2}{c}{ No Chewers } & \multicolumn{2}{c}{ Chewers } \\
\hline (mg\%) & Men & Women & Men & Women \\
Cholesterol & 201.75 & 193.50 & 155 & 150 \\
Triglycéride & 174 & 134 & 84 & 55 \\
\hline
\end{tabular}

\section{Discussion}

The results obtained in this research work are reflected in tables and figures that are detailed below. In Table 1 we observe in detail how the high Ande- an population under study were separated into two groups: the first corresponds to the control group, that is, those who do not chew coca leaves in both sexes, whose average age values are 45 years for men. and 40 years for women, in relation to weight with $80 \mathrm{~kg}$ for men and $65 \mathrm{~kg}$ for women. Depending on the size with $1.68 \mathrm{~m}$ for men and 1.55 for women.

Figure 1 Variation of serum cholesterol content $(\mathrm{mg} \%)$ in coca leaf chewers in relation to non-chewers

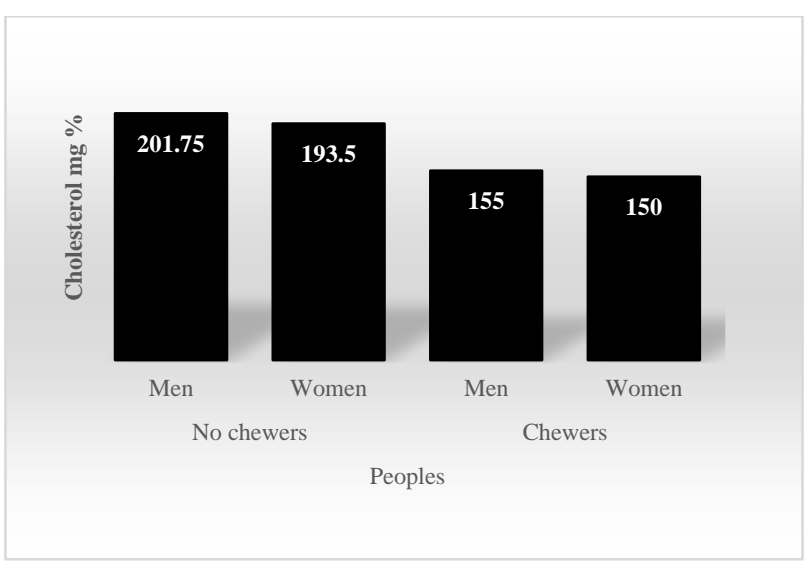

Figure 2 Variation of serum triglyceride content $(\mathrm{mg} \%)$ in coca leaf chewers in relation to non-chewers

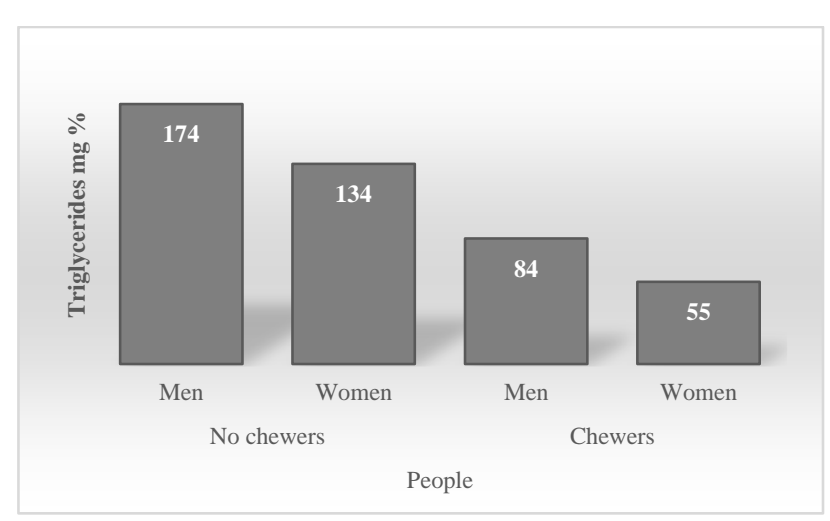

The second group made up of the problem group or the true coca leaf chewers in terms of the average age was 50 years for men and 45 years for women, $70 \mathrm{~kg}$ for men and $60 \mathrm{~kg}$ for women, and with the size of 1.61 for men and 1.50 for women. These 
results show that the high Andean people of the control group, who do not chew coca leaves, already in their diet is varied since the influence of the media has generated a change in habit, some people even dedicate themselves to fairs to the exchange of processed products, meat, milk among others, in terms of age they are young adults, with more muscle mass and weight and taller in height. However, people who chew coca leaves are older, light, and very short, which is why this difference is due. The coca leaf chewers do not have balanced food, sometimes they eat and more use the coca leaves for their work, avoid hunger and continue with their work, we have also noticed that they suffer a lot from digestive problems, hernias, and abdominal pain, Well, that corresponds to another research work.

Table 3 Simple correlation coefficient between cholesterol and serum triglyceride levels in coca leaf chewers and non-chewers, according to age, weight and height in both sexes

\begin{tabular}{cccccc}
\hline \multirow{2}{*}{ Variables } & \multirow{2}{*}{ Sex } & \multicolumn{2}{c}{ Serum cholesterol } & \multicolumn{2}{c}{ Serum trigliyeride } \\
\cline { 3 - 6 } & & Control group & Problem group & Control group & Problem group \\
\hline \multirow{2}{*}{ Age } & Female & 0.99 & 0.98 & 0.99 & 0.98 \\
& Male & 0.99 & 0.98 & 0.99 & 0.98 \\
\multirow{2}{*}{ Weigth } & Female & 0.99 & 0.98 & 0.99 & 0.98 \\
& Male & 0.99 & 0.98 & 0.99 & 0.98 \\
\multirow{2}{*}{ Size } & Female & 0.99 & 0.88 & 0.98 & 0.87 \\
& Male & 0.99 & 0.88 & 0.98 & 0.87 \\
\hline
\end{tabular}

The true chewers of dry coca leaves, do it together with a lime ash called "toqra", they do it from youth, adulthood and even the elderly, in their agricultural work, herding, fishing, patron saint festivals, wakes, mines Channels, constructions and arrangements of channels, they are generally thin and almost never obese, they weigh less than nonchewing people. Many have left this ancestral custom because they already have studied, because their children do not allow them, nor the type of work, they balance their eating habits because they also receive the support of social programs when they migrate to the cities.

Regarding size, we observe that coca leaf chewers are slightly shorter than city-dwellers because they do not consume balanced food in their constant agricultural work, the body needs energy and protein. Proteins in food fulfill essential and structural functions in living beings. However, these protein sources are of varying quality, with respect to hu- man beings, in addition to the cost, it is very difficult to access a peasant who chews coca leaves. Because good quality proteins are of high-cost animal origin, while lower quality vegetable proteins are more affordable to the economy of the rural population.

The averages of the serum tests are presented in $\mathrm{mg} \%$ of both the coca leaf chewers (problem group) and the non-chewers (control group). When relating cholesterol to the sex factor in Table 2, it was found that non-chewers of both sexes had high levels of cholesterol, obtaining $201.75 \mathrm{mg} \%$ men and 193.50 $\mathrm{mg} \%$ women, compared to chewers of coca leaves where $155 \mathrm{mg} \%$ corresponds to men and $150 \mathrm{mg} \%$ to women with normal cholesterol, which coincide with Cueto-García et $\mathrm{al}^{1 \mathbf{1 8}}$, who studied Mexican public servants and found the same trend, that is, cholesterol values of 195, 209, 217, and $211 \mathrm{mg} / \mathrm{dL}$, for the age groups: 20-29, 30-39, 40-49 and 50-59, respectively. In patients older than 60 years, the 
percentage cholesterol values decrease, which is probably explained because from that age on, lipid metabolism tends to stabilize compared to younger patients $\underline{18}$.

La Torre ${ }^{19}$ when studying serum cholesterol in normal people reported a mean value of $145.75 \mathrm{mg} \%$ in the female sex and $154.67 \mathrm{mg} \%$ in the male sex. Anaya et al. $\frac{20}{}$ determining serum cholesterol values in pregnant women, whose average figure is 239.9 $\mathrm{mg} \%$. Olivera ${ }^{21}$ when studying serum cholesterol in male university students, in two localities in the north of the country, with values of $280 \mathrm{mg} \%$ for Trujillo and $240 \mathrm{mg} \%$ for Cajamarca ${ }^{21}$. Age, weight, and sex up to 35 years of age, after which it increases more rapidly in men $\frac{22}{}$, are pointed out more than any other factor.

When relating triglycerides according to the sex variable, it is observed that the highest percentages of triglycerides correspond to the male sex of nonchewing people, it can be seen that they present 174 $\mathrm{mg} \%$, such as $134 \mathrm{mg} \%$ of the female population, compared to the net chewers of coca leaves with $84 \%$ that was obtained respectively in men and 55 $\mathrm{mg} \%$ in women. A higher prevalence of hypertriglyceridemia was obtained in men $(31.4 \%)$, compared to women, whose percentage was $7.8 \%$. This means that almost half of our study population had triglycerides considered slightly high, which coincides with a study by the Ministry of Health, in two districts of Lima, where they found a $44.2 \%$ prevalence of hypertriglyceridemia ${ }^{23}$. It is considered that low concentrations of lipid abnormalities in older adult patients may be associated with adverse health status and a decline in functional performance ${ }^{24}$. In this regard, in a study carried out on the coast of
Trujillo, it was reported that average triglyceride levels tended to decrease after 50 years and in both sexes $^{25}$.

Studying the relationship between lipid profile and body fat (BMI) in Indian patients, it was reported that the percentage of body fat was positively related to various lipid abnormalities, including hypercho-lesterolemia ${ }^{26}$. In patients with type II diabetes mellitus in Saudi Arabia, lipid abnormalities (including high total cholesterol) are related to high BMI, where $57.7 \%$ of male patients and $69 \%$ of female patients were overweight or obese $\mathrm{e}^{27}$.

Regarding the variation of the content of serum cholesterol $(\mathrm{mg} \%)$ in people who chew coca leaves in relation to non-chewers, it is shown in Figure 1, where the highest proportion of serum cholesterol levels correspond to non-chewers, which that indicates those who consume processed foods based on meat, cheese and other high cholesterol content on average $201.75 \mathrm{mg} \%$ in men and $193.50 \mathrm{mg} \%$ in women, that is, these people have a balanced diet. While the chewers of coca leaves average $155 \mathrm{mg} \%$ in men and $150 \mathrm{mg} \%$ in women, they occasionally try to balance their food, if there is money, they generally do not do it because they are extremely poor. These nutritional differences correspond to the complementary study that corresponds to research related to the human microbiota.

In 1999, according to the studies by HerreraCastillo ${ }^{\frac{13}{3}}$, only approximately $30 \%$ of the total circulating cholesterol is free, approximately $70 \%$ of the cholesterol in plasma lipoproteins is in the form of cholesterol esters, in which some long-chain fatty acid, normally linoleic acid is attached via an ester bond to the $\mathrm{OH}$ group of carbon-3 of ring $\mathrm{A}^{\frac{13}{3}}$. Cho- 
lesterol is a ubiquitous and essential component in mammalian cell membranes. Cholesterol, which can come from diet or de novo synthesis in practically all human cells, plays several important roles. It is the majority sterol in man, and a component of virtually all cell surfaces, as well as intracellular membranes. Cholesterol is particularly abundant in the myelinated structures of the brain and central nervous system, but it is also present in small amounts in the inner membrane of the mitochondria. Unlike what occurs in plasma, most of the cholesterol in cell membranes is in the free, non-esterified form. Cholesterol is also abundant in bile, at a concentration of $390 \mathrm{mg} / \mathrm{dL}$. In addition, cholesterol is the immediate precursor of bile acids that are synthesized in the liver and that act by facilitating the absorption of triacylglycerols and fat-soluble vitamins from the diet. It is important to understand that the ring structure of cholesterol cannot be metabolized to carbon dioxide and water in man. The route of excretion of cholesterol is carried out by the liver and the gallbladder through the intestine in the form of bile acids. Another physiological role of cholesterol is that of a precursor of various steroid hormones. Although steroid hormones are structurally related and come biochemically from cholesterol, they have very different physiological properties related to spermatogenesis, pregnancy, lactation, childbirth, mineral balance, and energy metabolism (amino acids, carbohydrates and fats) $)^{\frac{13}{3}}$.

In figure 2 we note the variation of the serum triglyceride content $(\mathrm{mg} \%)$ in people who chew coca leaves in relation to non-chewers. The highest values correspond to people who do not chew, where men have an average of $174 \mathrm{mg} \%$ and women 134 $\mathrm{mg} \%$, due to a balanced diet based on sheep and beef, as they have herds of this type of cattle. In relation to the triglyceride levels of the coca leaf chewers, the men with $84 \mathrm{mg} \%$ and the women 55 $\mathrm{mg} \%$, much lower data, this is based on the fact that the coca leaf chewers do not consume Due to their high costs, they prefer to chew coca leaves, only their children can sometimes consume alpaca meat that they raise, care for or herd other people's livestock.

There is little research related to the subject, such as Gutiérrez-Paredes ${ }^{2 \underline{8}}$ studied the effect of triglycerides on BMI, $47.4 \%$ had hypertriglyceridemia with normal BMI, those with high triglycerides correspond to $81.7 \%$ in people with overweight BMI and among obese patients, $69.9 \%$ presented the same lipid abnormality. These results coincide with that obtained by Llanos-Zavalaga et al..$^{29}$, who, when relating serum lipids with BMI, found an association between mild obesity and triglyceridemia ( $\mathrm{p}=$ 0.02). On the other hand, Martínez-Palomino et al. $\frac{30}{}$, in a study with young Mexican women, found that there were differences with statistical significance when relating triglycerides with BMI. However, when studying apparently healthy people, whose ages fluctuated between 15 and 25 years with averages of $85.22 \mathrm{mg} \%$ for women and 100.44 $\mathrm{mg} \%$ for men, values lower than ours for this magnitude ${ }^{\frac{19}{}}$. Fattorusso \& Ritter ${ }^{31}$ indicate normal values between 40 to $185 \mathrm{mg} \%$. Which also coincides with the present work. It should be mentioned that the highest prevalence of lipid abnormalities (both cholesterol and triglycerides) were obtained in overweight patients and not, in obese patients, as should be expected. 
The action of bile salts, detergent substances that are synthesized in the liver and stored in the gallbladder, is essential for the digestion of lipids and their absorption through the intestinal mucosa. The problem of transport through blood and lymph is solved, in part, by complexing lipids with proteins to form soluble aggregates called lipoproteins. Fat digestion products comprise a mixture of glycerol, free fatty acids, monoacylglycerides, and diacylglycerides. During absorption through the cells of the intestinal mucosa, abundant resynthesis of triacylglycerides occurs from the hydrolysis products. Triacylglycerides end up in the lymphatic system forming complexes with proteins to give rise to lipoproteins called chylomicrons. Chylomicrons are the way food fat is transported from the intestine to peripheral tissues, especially the heart, muscle, and adipose tissue. Very low-density lipoproteins (VLDL) play a comparable role for triacylglycerides synthesized in the liver. The triacylglycerides in both lipoproteins hydrolyze to glycerol and fatty acids on the internal surfaces of capillaries in peripheral tissues. This hydrolysis involves an activation of the extracellular enzyme lipoprotein lipase by apoprotein C-II. Some of the released fatty acids are absorbed by nearby cells, while others remain fairly insoluble, complexing with serum albumin to be transported to more distant cells. After absorption into the cell, fatty acids from the action of lipoprotein lipase can be catabolized to generate energy or, in fat cells, used to re-synthesize triacylglycerides.

The fatty acids released by the hydrolysis of triglycerides undergo successive oxidation, depending on the body's demand, turning into Acetyl CoA mole- cules. This central intermediate compound can also undergo its conversion to cholesterol, since for its biosynthesis it requires a source of carbon atoms and all the carbon atoms of cholesterol come from Acetyl $\sim \mathrm{CoA}$, in its acetate forms $\frac{32}{}$.

Free fatty acids in the circulation come from the lipolysis of triglycerides in adipose tissue. Fatty acids are the precursors of ketone bodies in the liver. An important ketone body is acetoacetate, which is formed from acetoacetyl-CoA, this pathway involves the condensation of acetoacetyl-CoA with another acetyl-CoA molecule to form 3-hydroxy-3methylglutaryl-CoA (HMG-CoA). HMG-CoA is a key metabolite in the biosynthetic pathway of cholesterol, that is, there is a metabolic crossroads that makes it possible to direct said metabolite to the synthesis of cholesterol or ketone bodies $\underline{28}$.

Although ketogenesis is carried out in the mitochondria, and cholesterol biosynthesis is extramitochondrial, there is a less active pathway in the cytosol of liver cells, where acetoacetyl-CoA is the precursor in the synthesis of cholesterol ${ }^{33}$.

Cardiovascular disease (CVD) is primarily responsible for the global burden of noncommunicable disease (32 million). The $\mathrm{WHO}^{34}$ attributes that currently the majority of deaths registered worldwide are attributable to CVD (16.7 million); of which more than a third are in middle-aged adults. Currently, in developing countries the number of deaths attributable to CVD is twice as high as in developed countries. The main risk factors for CVD are: tobacco use, an inadequate diet and lack of physical activity (which mainly results in unhealthy lipid concentrations and / or a high body mass index) are the cause of $75 \%$ and $85 \%$ of new cases are 
of coronary heart disease ${ }^{1}$. Obesity represents one of the main public health problems that carry risks in the increase and accumulation of body fat, which translates into an increase in the body mass index (BMI), being an indicator of morbidity and mortality which must be to numerous chronic diseases such as: hypertension, type 2 diabetes mellitus and $\mathrm{CVD}^{34}$. Obesity and overweight are a global epidemic, a pandemic recognized by the WHO, which has important health consequences when presenting CVD (mainly coronary heart disease and strokes). In Peru, overweight and obesity are higher in adults and in women from coastal areas who come from non-poor strata; A worrisome situation since according to the National Institute of Statistics and Informatics (INEI) $73.6 \%$ of Peruvians live in urban areas $\underline{35}$.

In Table 3, the simple correlation coefficient between cholesterol and serum triglyceride levels in people who chew coca leaves and who do not chew, according to age, weight and height in both sexes. The linear correlation coefficient is the quotient between the covariance and the product of the standard deviations of both variables. The linear correlation coefficient is represented by the letter $r$. whose properties are: the correlation coefficient does not vary as the measurement scale does. That is, if we express the height in meters or centimeters, the correlation coefficient does not vary. The sign of the correlation coefficient is the same as that of the covariance. If the covariance is positive, the correlation is direct. If the covariance is negative, the correlation is inverse. If the covariance is zero, there is no correlation. That is, the linear correlation coefficient is a real number between -1 and 1 . If the linear correlation coefficient takes values close to 1 , the correlation is strong and direct, and it will be stronger the closer it is to 1 . Yes the linear correlation coefficient takes values close to 0 , the correlation is weak. Our results for both age, weight and height are close to 1 , which is why it is positive and direct $\frac{36}{}$.

Finally, it should be mentioned that the reason for our research within the high Andean population was to find out if they use processed or junk foods based on fats or lipids: cholesterol and triglycerides, despite the propaganda by the media, they influence the children of peasants, farmers and small ranchers. Many are leaving their habits of feeding on products of the land: vegetable grains, tubers, legumes, vegetables, trout meat, guinea pig and alpaca.

However, there is a sector of extreme poverty that are the chewers of coca leaves that live in the high Andean areas as peasants or farmers, and alpaca keepers. When they emigrate to the jungle cities they are settlers and dedicate themselves to growing coca and other fruit trees, on the other hand, those who survive in coastal and mountain cities continue with this ancestral custom of working as laborers, helpers, solid waste collectors, collectors of cotton and grapes, they save to educate their children.

\section{Funding source}

To the Faculty of Biological Sciences of the National University of San Cristóbal de Huamanga for the support provided.

\section{Conflicts of interest}


The author expresses that there is no conflict of interest

\section{Acknowledgments}

To the director of the Hospital de Apoyo de Pausa. Ministry of Health, who authorized the collection of the samples, in the same way to the National University of San Cristóbal de Huamanga.

\section{Ethical considerations}

All procedural aspects were approved by the Faculty of Biological Sciences.

Protection of people and animals. The authors declare that for this research they did not carry out experiments on humans or animals.

Confidentiality of data. The authors who have followed the protocols of their work center on the publication of patient data.

Right to privacy and informed consent. The authors declare that no patient data appear in this article.

\section{Cited Literature}

1. Landa Pizarro PK, Obregón Rojas NK. Uso de la coca desde la cosmovisión andina en el proceso histórico peruano [tesis licenciatura]. [Huancayo]: Universidad Nacional del Centro del Perú; 2014 [citado el 31 de agosto de 2020]. Recuperado a partir de: http://repositorio.uncp.edu.pe/handle/

\section{$\underline{\mathrm{UNCP} / 1705}$}

2. Cordero Vilca TA. Evaluación nutricional de la proteína de hojas de coca Erythroxylum coca Lamarck var. coca [tesis licenciatura]. [Lima]: Universidad Nacional Mayor de San Marcos; 2002. [citado el 31 de agosto de 2020]. Recuperado: http://cybertesis.unmsm.edu.pe/handle/20.500.12 $\underline{672 / 1088}$

3. Olascoaga G. La coca peruana en relación con la industria Nacional. [Lima]: Universidad Nacional de San Marcos; 1942.

4. Chocce Flores D. Funciones de la hoja de coca durante el proceso de violencia política en el centro poblado de San José de Villa Vista, Distrito de Chungi, Provincia de La Mar, Región Ayacucho [tesis licenciatura]. [Huancayo]: Universidad Nacional del Centro del Perú; 2015 [citado el 31 de agosto de 2020]. Recuperado a partir de: http://repositorio.uncp.edu.pe/handle/UNCP/87

5. Chaud A, Espejo H, Makino E, Horna E, Ayala L. Estudio de proteínas totales y fraccionadas en indígenas que mascan la coca. Rev Med Hospital Central del Empleado 1967.

6. Ungaro M. Patología oral en masticadores de hojas de coca. [tesis doctoral]. [Lima]: Universidad Peruana Cayetano Heredia; 1972.

7. Caravedo Carranza B, Almeida Vargas M. Alcoholismo y toxicomanías [Internet]. Lima: Ministerio de Salud; 1972 [citado 22 de octubre de 2020]. 72 p. Recuperado a partir de: http://bvs.minsa.gob. pe/local/minsa/2319.pdf

8. Cabieses F. Etnología, fisiología y farmacología de la coca y la cocaína. Museo Peruano de Ciencias de la Salud; 1985.66 p.

9. Ochoa B, Diez J, Anaya B, Mujica F. Proteínas totales en masticadores de hojas de coca. En: Ochoa B, Diez J, Anaya B, Mujica F, editores. Jornadas Peruanas de Bioquímica; 1998. Lima.

10.Obregón Lujerio AF. Transformación de las hojas de coca (Erythroxylum coca Lamarck) en pan para consumo humano y su impacto socioeconómico y ambiental en las ciudades del Alto Huallaga [tesis doctoral]. [Trujillo]: Universidad Nacional de Trujillo; 2010 [citado 26 de octubre de 2020]. Recuperado a partir de: 
http://dspace.unitru.edu.pe/ handle/UNITRU/5212

11.Zavaleta Martínez A. Anatomía de la hoja de coca, falacias acerca de sus componentes químicos, la medicina y la adicción. Rev Cedro Gráfica Macole S.R.L. 2011.

12.Hurtado C. Harina de coca: solución del hambre, malnutrición en el Perú. [Lima]: Edit. Juan Gutenberg; 2008.

13.Herrera Castillón E. Bioquímica. Aspectos estructurales y vías metabólicas. Vol 1. Edit. Madrid: Interamericana-MC Graw Hill; 1996.

14. Sentí M, Masía R, Pena A, Elosua R, Aubó C, Bosch $\mathrm{M}$, et al. Determinantes antropométricos y dietéticos de la concentración sérica del colesterol de las lipoproteínas de alta densidad en un estudio de base poblacional. El estudio REGIDOR. Rev Esp Cardiol 1998;51(12):979-87.

15.Peña M, Bacallao J. La obesidad y sus tendencias en la región. Rev Panam Salud 2001;10(2):75-8. DOI: https://doi.org/10.1590/S1020-4989200100 $\underline{0800001}$

16. Valtek Diagnostics. Colesterol HDL (Método directo [Internet]. Santiago de Chile: Valtek S.A.; 2015 [citado 6 de abril de 2016]. 2 p. Recuperado a partir de: http://www.andinamedica.com.pe/wpcontent/uploads/2017/10/valtelk-hdl-directo.pdf

17.Valtek Diagnostics. Triglicéridos-LS (GPO-PAP) [Internet]. Santiago de Chile: Valtek S.A.; 2015 [citado 6 de abril de 2016]. 2 p. Recuperado a partir de: http://andinamedica.com.pe/wpcontent/ uploads/2016/08/VTK-trigliceridos.pdf

18. Cueto García L, Brito E, Barrera Guerrero J, Gutiérrez Ávila MC. Prevención de la aterosclerosis coronaria (III) prevalencia de factores de riesgo en burócratas de la ciudad de México DF. Arch Inst Cardiol Mex 1989;59:19-27.

19.La Torre L. Determinación de lípidos totales, triglicéridos y colesterol sérico en personas apa- rentemente sanas [tesis licenciatura]. [Ayacucho]: Universidad Nacional de San Cristóbal de Huamanga; 1978.

20.Anaya B, Huasasquiche P, Ochoa V. Determinación del colesterol, hemoglobina y hematocrito en gestantes de la localidad. [Ayacucho]: Universidad Nacional de San Cristóbal de Huamanga. Publicación Nº 2 Área Bioquímica; 1982.

21.Olivera A. Boletín de la Sociedad Química del Perú; 1973.

22. Sarraillet J. El IOMA reconoce el colesterol HDL. Revista Bioquímica Clínica. 1985.

23. Rosas Aguirre A, Lama G, Llanos Zavalaga F, Dunstan J. Prevalencia de obesidad e hipercolesterolemia en trabajadores de una institución estatal de Lima - Perú. Rev Perú Med Exp Salud Pública 2002;19(2):87-92.

24.Suka M, Yoshida K, Yamauchi K. Impact of body mass index on cholesterol levels of Japanese adults. Int J Clin Prac 2006;60(7):770-82. DOI: $\quad$ https://doi.org/10.1111/j.1368$\underline{5031.2006 .00946 . x}$

25.Huamán Saavedra J. Hiperlipidemia en una población laboral. Rev Med Perú 1997;69:25-9.

26. Arora M, Koley S, Gupta S, Sandhu JS. A study on lipid profile and body fat in patiens with diabetes mellitus. Anthopologist 2007;9(4):295-8. DOI:

https://doi.org/10.1080/09720073.2007.11891015

27.El-Hazmi MF, Al-Swailem AR, Warsy AS, AlMeshari AA, Sulaimani R, Al-Swailem AM, et al. Lipids and related parameters in Saudi tipe II diabetes mellitus patients. Ann Saudi Med 1999;19(4):304-7. DOI: https://doi.org/10.5144/0 256-4947.1999.304

28. Gutiérrez Paredes EE. Colesterol y triglicéridos y su relación con el índice de masa corporal (IMC) en pacientes adultos que acuden al Servicio Académico Asistencial de Análisis Clínicos 
(SAAAC) [tesis licenciatura]. [Lima]: Universidad Nacional Mayos de San Marcos; 2009 [citado el 31 de agosto de 2020]. Recuperado: http://cybertesis. unmsm.edu.pe/handle/20.500.12672/3257

29.Llanos Zavalaga F, Nájar Trujillo NE, Mayca Pérez J, Rosas Aguirre A. Prevalencia de obesidad e hipercolesterolemia en la Facultad de Medicina de la Universidad Peruana Cayetano Heredia-1998. Rev Med Hered 2001;12(3):78-84. DOI: https:// doi.org/10.20453/rmh.v12i3.2388

30.Martínez Palomino G, Vallejo M, Huesca C, Alvarez de León E, Paredes G, Lerma Gonzáles C. Factores de riesgo cardiovascular en una muestra de mujeres jóvenes mexicanas. Arch Card Mex 2006;76(4):401-7.

31.Fattorusso V, Ritter O. Vademécum clínico del síntoma a la receta. [España]. Edit. El Ateneo; 1981.

32.González Sandoval CE, Díaz Burke Y, Mendizábal Ruiz AP, Medina Díaz E, Morales JA. Prevalencia de obesidad y perfil lipídico alterado en jóvenes universitarios. Nutr Hosp 2014;29(2):315-21. DOI: https://doi.org/10.3305/nh.2014.29.2. 7054

33. Osorio JH, Aguirre CA. Relación entre el metabolismo de los triglicéridos y aterosclerosis en el hipercolesterolemia Familiar. Biosalud 2013;12(1): 39-48.

34.Epidemias mundiales desatendidas: tres amenazas crecientes [Internet]. Organización Mundial de la Salud. Informe sobre la salud en el mundo. 2003.

Recuperado: https://apps.who.int/iris/handle/1066 5/69080

35.Custodio Cerezales E, Bernis Carro C, Barroso Benitez A, Montero López P, Varea González C. Riesgo cardiovascular en mujeres españolas de 45 a 68 años: el papel de la ferritina. Rev Antropo 2003;4:1-15. España.
36. Morales Vallejo P. Correlación y regresión, simple y múltiple [Internet]. Madrid: Universidad Pontificia Comillas; 2011 [citado 22-de octubre de 2020]. 24 p. Recuperado a partir de: http://upav-biblioteca.org/site/wpcontent/uploads/2017/10/ 11-Introduccion-a-laregresion.pdf

Editor's Note:

Journal of the Selva Andina Research Society (JSARS) remains neutral with respect to jurisdictional claims published on maps and institutional affiliations. 